\title{
Isolated pancreatic injury in an adolescent treated with Roux-en-Y pancreatojejunostomy: a case report and review of the literature
}

\author{
Mohamed Eltayeb Abdelrahman Naiem ${ }^{1 *}$ (D) and Nassir Alhaboob $\mathrm{Arabi}^{2}$
}

\begin{abstract}
Background: Pancreatic injury presented as isolated injury in the pediatric population is exceptionally rare, with a conveyed incidence of less than $2 \%$ of all abdominal trauma injuries cases and a very controversial management approach for grade III injuries.

Case presentation: A 16-year-old adolescent Sudanese boy was referred to our emergency department with a 5-day history of upper and left hypochondrial pain after blunt abdominal trauma to the epigastric region with a solid object. Grade III pancreatic body trauma with major duct involvement can be successfully treated operatively. The boy was discharged home on day 10 with regular oral intake and diet. A follow-up for 6 months continued by phone, and it was uneventful with no further complications.
\end{abstract}

Conclusions: Roux-en-Y pancreatojejunostomy reconstruction can be a safe and valuable surgical option when the surgical approach is considered for grade III pancreatic injury.

Keywords: Pancreatic blunt trauma, Major duct injury, Roux-en-Y pancreatojejunostomy

\section{Introduction}

Blunt abdominal injury causing significant and major pancreatic injury is rare in adolescents and young adults, with a controversial approach to its management. The position of the pancreas in the retroperitoneal region makes isolated injury a rare entity and resembles a challenge for the surgeon. It is graded into five grades ranging from minor contusion or small laceration without duct injury to major pancreatic duct or head disruption and transection according to the Association for the Surgery of Trauma organ injury scale (AAST-OIS). Management options range from a conservative approach to major pancreatic resection and complex reconstruction.

*Correspondence: M-altayeb@live.com

${ }^{1}$ Faculty of Medicine, University of Khartoum, Khartoum, Sudan

Full list of author information is available at the end of the article

\section{Case presentation}

A 16-year-old adolescent Sudanese boy was referred to our emergency department with a 5-day history of upper and left hypochondrial pain after blunt abdominal trauma to the epigastric region with a solid object. His pain was dull-aching in nature, localized to the epigastrium and left hypochondrial areas, aggravated and increased by movement and partially relieved by analgesia, but he had no fever, radiation, nausea, vomiting, or other associated symptoms. He had a clear medical and surgical background with a complete vaccination history. He is not allergic to any drugs or chronic medications. On examination, he was fully conscious, oriented, and aware of his surroundings, slightly pale but not jaundiced. His pulse rate was 120 beats per minute, and he was hypotensive with a blood pressure of $95 / 50 \mathrm{mmHg}$ and slightly dehydrated. Abdominal examination revealed moderated epigastric and left hypochondrial tenderness with guarding but no rigidity, with hypoactive original author(s) and the source, provide a link to the Creative Commons licence, and indicate if changes were made. The images or other third party material in this article are included in the article's Creative Commons licence, unless indicated otherwise in a credit line to the material. If material is not included in the article's Creative Commons licence and your intended use is not permitted by statutory regulation or exceeds the permitted use, you will need to obtain permission directly from the copyright holder. To view a copy of this licence, visit http://creativecommons.org/licenses/by/4.0/. The Creative Commons Public Domain Dedication waiver (http://creativeco mmons.org/publicdomain/zero/1.0/) applies to the data made available in this article, unless otherwise stated in a credit line to the data. 
sluggish bowel sounds. No organomegaly masses were detected. The systemic review was clear, and no abnormality was detected. Blood investigations were requested, and hemoglobin $(\mathrm{Hb})$ of $8.5 \mathrm{~g} / \mathrm{dl}$ was revealed with normal white blood cell (WBC) count and platelets (PLTs). Urinalysis and blood electrolytes were normal. A CECT abdomen was performed before referral, and it showed lesser sac collection/hematoma with suspected grade III splenic injury and suspected pancreatic parenchymal injury; no other organ injury was detected (Fig. 1). The absence of magnetic resonance cholangiopancreatography (MRCP)/endoscopic retrograde cholangiopancreatography (ERCP) facilities supported the decision for emergency laparotomy after adequate resuscitation as the patient's pain scale increased since the injury to presentation and vital sign charts were suggestive of intraperitoneal bleed correlating with the provisional diagnosis of splenic injury grade III.

An exploratory laparotomy through upper midline incision revealed a normal spleen with a clear, thick fluid collection in the lesser sac and contused pancreas with peripancreatic hematoma and anterosuperior distal pancreatic body laceration with major duct injury of $(1 \times 1.2 \mathrm{~cm}$ punched-out pancreatic parenchymal tissue) approximately, involving pancreatic parenchyma and duct with preservation of the posterior duct wall and communication with the lesser sac collection and intact posterior parenchyma and pancreatic magna and splenic arteries confirming the diagnosis of grade III injury American Association for the Surgery of Trauma organ injury scale (AAST-OIS) intraoperatively.
Lesser sac was accessed through the opening of the lesser omentum, careful examination of the pancreas, spleen, and major vascular structures. Peripancreatic wash, sample for amylase taken, debridement of the injury, and intraoperative discussion were made to drain the bed versus performing Roux-en-Y pancreatojejunostomy, and surgical reconstruction was the agreed option.

Roux-en-Y pancreatojejunostomy reconstruction was made in a retro-colic position, a Roux limb of $50 \mathrm{~cm}$ length and $8 \mathrm{~mm}$ enterotomy in the antimesenteric border, side to side, single layer with a full-thickness pancreatic-jejunal (duct to mucosa) anastomosis using $4 / 0$ polydioxanone (PDS) interrupted stitches between the jejunum and pancreatic duct and parenchyma with augmenting corner stitches. Jejunojejunostomy was reconstructed with a $40 \mathrm{~cm}$ jejunal limb from the ligament of Treitz applying a hand-sewn, two-layer technique with $3 / 0$ vicryl sutures (Fig. 2), pancreatic bed and peritoneal drainage in situ, and standard abdominal mass closure. Peritoneal fluid amylase tested positive, and oral intake started on day 3 postoperation. Drainage became dry on day 6 postoperation, and the patient was discharged home on day 10 with regular oral intake and diet.

A follow-up for 6 months continued by phone, and it was uneventful; he went back to his work as a shepherd after 3 months and gained significant weight.

\section{Discussion}

Pancreatic injury presented as isolated injury in the pediatric population is infrequent, with a conveyed incidence of less than $2 \%$ of all abdominal injuries cases [1-3].

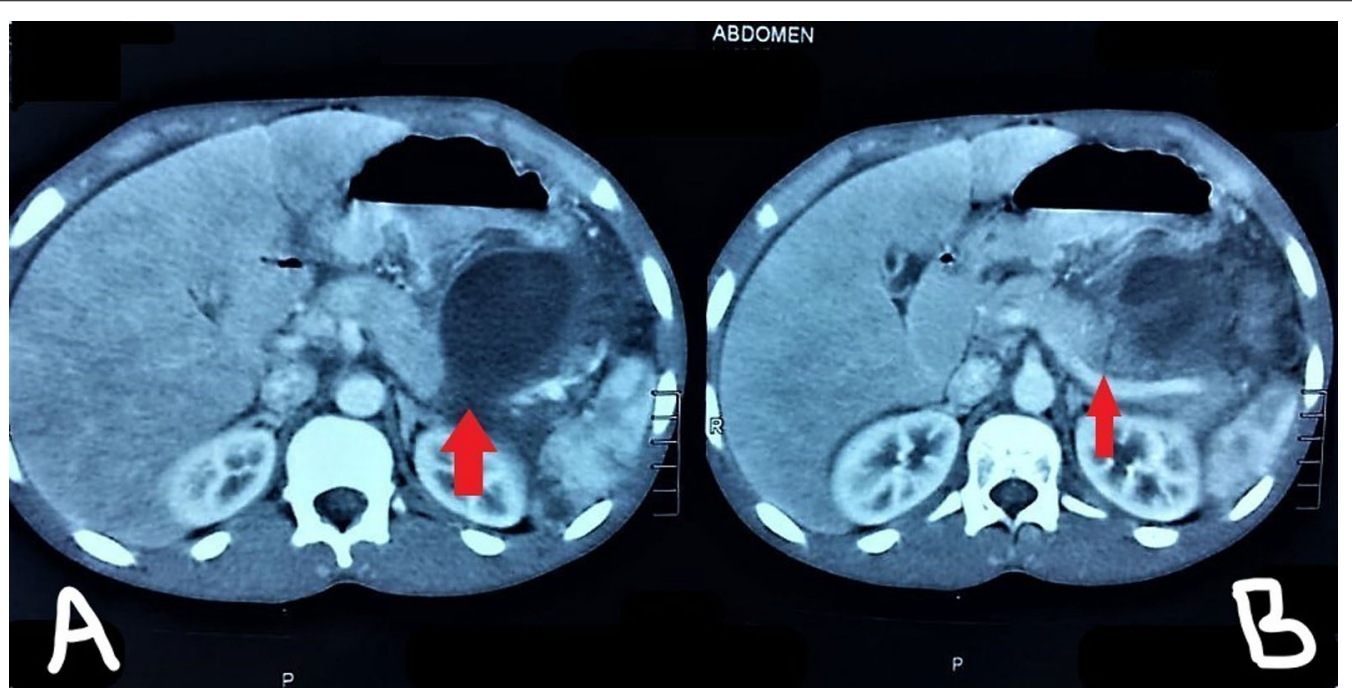

Fig. 1 Computed tomographic scan of the abdomen showing the pancreatic injury and peripancreatic collection. A - Left: Arrow represents peripancreatic collection communicating with injured pancreatic parenchyma and duct. B - Right: Arrow represents Pancreatic duct injury at the body of the pancreas. All patient related identifications were anonymized 


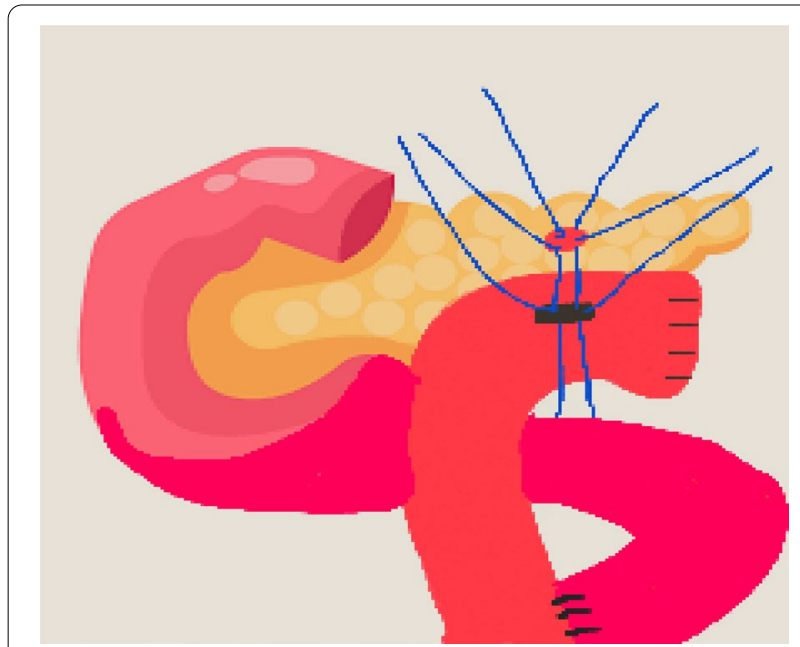

Fig. 2 Roux-en-Y pancreatojejunostomy diagram demonstration

Nevertheless, it can be associated with significant comorbidities and mortality in a low-resource country.

It requires accurate observation and diagnosis as it mandates surgical intervention, especially when major duct injury is concerned [4]. Such uncommon injuries, especially those that are low-grade in nature, subclinical, or presenting with delayed complications, can be managed conservatively with favorable outcomes, as experienced in a reported series with male predominance related to male involvement in more traumatic activities. A multicenter study reported by Iqbal et al. concluded that grade II injuries should be managed nonoperatively, whereas grade III injuries should be managed by operative resection. However, grade III trauma with major duct involvement can be challenging and controversial [2, 5-7]. According to Krige et al., the postoperative complication and fatality rate in a single institute of 49 patients with isolated pancreatic injuries was $55 \%$ and $4 \%$, consistently [8]. In a Korean study, Chi et al. described that the morbidity and mortality of 20 isolated pancreatic injuries were $65 \%$ and $0 \%$, respectively [9]. The majority of type II and III injuries are now managed conservatively in the absence of indications for emergency exploration. Conservative management approach includes retaining the patient Nil Per Os (NPO), administration of intravenous solutions and somatostatin analog drugs and protonpump inhibitors (PPIs), and relentless monitoring of vital signs, warning signs, and symptoms of peritonitis until the patient can safely tolerate oral intake [10].

Anterior Roux-en-Y pancreatojejunostomy was convenient in our case report after debridement of the wound area and the visually intact posterior pancreatic parenchyma [7]. The pancreatic duct injury in which pancreatic tissue was not transacted was distal to the head and neck (grade III). Utilizing this operative technique, we protected the patient from major pancreatic resection operations complications and prolonged general anesthesia complications in a critically ill trauma patient. In this operation, there was no necrotic tissue on the posterior wall of the pancreas, so the anastomosis was smaller than dunking pancreatic anastomosis, which was employed in Whipple's procedure. Furthermore, the risk of anastomotic leakage is decreased. Additionally, insufficient debridement increases the probability of anastomosis leakage and can be reduced by undertaking adequate debridement [7].

An international agreement indicated that grade I-II injuries should be managed nonoperatively. In a multicenter cohort study of children with grade II and grade III pancreatic injuries, operative and conservative strategies emerged to be equivalent $[11,12]$. Both grades of injury (II and III) represent an area of controversy and discussion to compare nonoperative versus operative management protocol and indications as many factors guide patient management according to patient status and centers' capability to provide required imaging and interventional modalities if needed. A universal standardized protocol and consensus must be established to manage these serious forms of injuries $[11,13,14]$.

\section{Conclusion}

Grade III pancreatic isolated injury management remains controversial and situation-dependent, but due to the patient condition and lack of obtainability of ERCP at the time of presentation, operative management and Rouxen-Y pancreatojejunostomy reconstruction was the optimal and safe approach.

\section{Abbreviations}

CECT Abdomen: Contrast-enhanced computed tomography scan; ERCP. Endoscopic retrograde cholangiopancreatography; AAST-OIS: American Association for the Surgery of Trauma organ injury scale.

\section{Acknowledgements}

We acknowledge the medical records team for their help.

\section{Authors' contributions}

MEAN carried out the initial assessment and resuscitation at the emergency department. MEAN and NAA contributed to patient management during admission, surgical intervention, and postoperative follow-up, writing, and coordination in the alignment to draft the manuscript. Both authors read and approved the final manuscript.

\section{Funding}

We declare that there was no funding.

\section{Availability of data and materials}

The datasets used during the current study are available from the corresponding author on reasonable request. All medical data, supporting materials, and images are available upon request. 


\section{Declarations}

Ethics approval and consent to participate

Ethical approval for publishing this case report has been obtained from the Fedail Hospital/local hospital ethical committee.

\section{Consent for publication}

Written informed consent was obtained from the patient's legal guardian to publish this case report and any accompanying images. A copy of the written consent is available for review by the Editor-in-Chief of this journal.

\section{Competing interests}

All authors declare that they have no competing interests.

\section{Author details}

${ }^{1}$ Faculty of Medicine, University of Khartoum, Khartoum, Sudan. ${ }^{2}$ Department of Gastrointestinal and Hepato-Pancreatic-Biliary Surgery, Ibn Sina Specialized Hospital, Khartoum, Sudan

Received: 21 May 2021 Accepted: 2 August 2021

Published online: 16 September 2021

\section{References}

1. Cirillo RL, Koniaris LG. Detecting blunt pancreatic injuries. J Gastrointest Surg. 2002;6(4):587-98.

2. Iqbal CW, St Peter SD, Tsao K, Cullinane DC, Gourlay DM, Ponsky TA, Wulkan ML, Adibe OO. Operative vs nonoperative management for blunt pancreatic transection in children: multi-institutional outcomes. J Am Coll Surg. 2014;218(2):157-62.

3. Moore EE, Cogbill TH, Malangoni MA, Jurkovich GJ, Champion HR, Gennarelli TA, McAninch JW, Pachter HL, Shackford SR, Trafton PG. Organ injury scaling, Il: pancreas, duodenum, small bowel, colon, and rectum. J Trauma. 1990;30(11):1427-9.
4. Kao LS, Bulger EM, Parks DL, Byrd GF, Jurkovich GJ. Predictors of morbidity after traumatic pancreatic injury. J Trauma Acute Care Surg. 2003;55(5):898-905.

5. Canty TG Sr, Weinman D. Management of major pancreatic duct injuries in children. J Trauma Acute Care Surg. 2001;50(6):1001-7.

6. Lochan R, Sen G, Barrett AM, Scott J, Charnley RM. Management strategies in isolated pancreatic trauma. J Hepatobiliary Pancreat Surg. 2009;16(2):189-96.

7. Sahin S, Duruk R, Ceylan C, Cetinkaya E, Tez M. Isolated pancreas injury by blunt trauma, a case report. Trauma Cases Rev. 2016;2:046.

8. Krige JE, Kotze UK, Nicol AJ, Navsaria PH. Isolated pancreatic injuries: an analysis of 49 consecutive patients treated at a Level 1 Trauma Centre. J Visc Surg. 2015;152(6):349-55.

9. Chi HS, Choi SY, Cho JP, Kim BR, Lee KS. Comparative studies between isolated pancreatic injury and associated with other organs. J Korean Surg Soc. 1991:41(4):431-8.

10. Zhang D, Yan J, Siyin ST, Pang W, Chen Y. Nonresection management of the pancreas for grade III and IV blunt pancreatic injuries in children: a single center's experience. BMC Pediatr. 2021;21(1):1-9.

11. Paul MD, Mooney DP. The management of pancreatic injuries in children: operate or observe. J Pediatr Surg. 2011;46(6):1140-3.

12. Cuenca AG, Islam S. Pediatric pancreatic trauma: trending toward nonoperative management? Am Surg. 2012;78(11):1204-10.

13. Menahem B, Lim C, Lahat E, Salloum C, Osseis M, Lacaze L, Compagnon P, Pascal G, Azoulay D. Conservative and surgical management of pancreatic trauma in adult patients. Hepatobiliary Surg Nutr. 2016;5(6):470.

14. Meier DE, Coln CD, Hicks BA, Guzzetta PC. Early operation in children with pancreas transection. J Pediatr Surg. 2001;36(2):341-4.

\section{Publisher's Note}

Springer Nature remains neutral with regard to jurisdictional claims in published maps and institutional affiliations.
Ready to submit your research? Choose BMC and benefit from:

- fast, convenient online submission

- thorough peer review by experienced researchers in your field

- rapid publication on acceptance

- support for research data, including large and complex data types

- gold Open Access which fosters wider collaboration and increased citations

- maximum visibility for your research: over $100 \mathrm{M}$ website views per year

At BMC, research is always in progress.

Learn more biomedcentral.com/submissions 